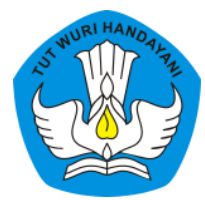

Page: $47-70$

\title{
PENGGUNAAN SIM-ROSI BERBASIS PjBL DAN STEAM UNTUK MENINGKATKAN KETERAMPILAN ABAD 21 BAGI PESERTA DIDIK SEKOLAH DASAR
}

\author{
Ah. Burhanudin \\ Sekolah Dasar Negeri Langenharjo 2 Kabupaten Kediri, Jawa Timur, Indonesia \\ Contributor Email: ahburhanudin12@gmail.com
}

Received: Feb 13, 2021

Accepted: Mar 9, 2021

Published: Mar 30, 2021

Article Url: https://ojsdikdas.kemdikbud.go.id/index.php/didaktika/article/view/231

\begin{abstract}
Teachers as the spearhead of education who are directly related to students are expected to be able to provide positive content in fostering the characteristics of 21st century learning, in the form of: critical thinking, problem solving, collaboration, and communication (4C). The purpose of these activities is to be able to equip and foster creativity, productivity, and to prepare students for the progress of the 21st century. Based on preliminary observations, it is known that learning triggers the growth of 21 st century characteristics (4C) in grade 3 students of Langenharjo 2 Elementary School in the learning process. very low. Simple Rocket Design (SIM-ROSI) is a design developed as a solution to improve the quality of student learning. Developed with a $4 D$ development research model according to Thiagarajan. Supported by the implementation of Project Based Learning (PjBl) -based learning and Engineering Science Technology Art and Math (STEAM). Development success indicators are based on observations of students' $4 C$ activities in learning. The collected data were analyzed using descriptive analysis and statistical tests using paired sample t-test. The results of the analysis show the conclusion that SIM-ROSI based on PjBL and STEAM is very effective in increasing the $4 C$ activities of students in thematic learning in elementary schools.
\end{abstract}

Keywords: Sim-Rosi; Project Based Learning; STEAM; 21st century skills 


\begin{abstract}
Abstrak
Guru sebagai ujung tombak pendidikan yang berhubungan langsung dengan peserta didik diharapkan mampu memberikan muatan positif dalam menumbuhkan karakteristik pembelajaran abad 21, berupa: critical thinking, problem solving, collaboration, dan communication (4C). Tujuan kegiatan tersebut adalah agar dapat membekali dan menumbuhkan kreativitas, produktivitas, dan mempersiapkan peserta didik menghadapi kemajuan abad 21. Berdasar observasi awal diketahui bahwa pembelajaran yang memicu tumbuhnya karakteristik abad 21 (4C) pada peserta didik kelas 3 Sekolah Dasar Negeri Langenharjo 2 dalam proses pembelajaran sangat rendah. Simple Rocket Design (SIM-ROSI) merupakan rancangan yang dikembangkan sebagai sebuah solusi untuk memperbaiki kualitas belajar peserta didik. Dikembangkan dengan model penelitian pengembangan 4D menurut Thiagarajan. Ditunjang dengan pelaksanaan pembelajaran berbasis Project Based Learning (PjBl) dan Sains, Technologi, Enginering, Art, and Math (STEAM). Indikator keberhasilan pengembangan berdasar observasi terhadap aktivitas $4 \mathrm{C}$ peserta didik dalam pembelajaran. Data yang terkumpul dianalisis menggunakan analisis deskriptif dan uji statistik menggunakan paired sample t-test. Hasil analisis menunjukkan simpulan bahwa SIM-ROSI berbasis PjBL dan STEAM sangat efektif digunakan untuk meningkatkan aktivitas $4 C$ peserta didik di dalam pada pembelajaran tematik di sekolah dasar.
\end{abstract}

Kata Kunci: Sim-Rosi; Project Based Learning; STEAM; Keterampilan abad 21

\title{
A. Pendahuluan
}

Pemerintah Indonesia selalu berusaha untuk melakukan pengembangan dunia pendidikan. Kurikulum 2013 adalah suatu bentuk usaha pemerintah untuk melakukan perbaikan dan perubahan tersebut. Kurikulum ini merupakan sebuah sistem kurikulum yang sesuai dengan kebutuhan peserta didik pada pembelajaran abad 21. Yaitu sebuah sistem pendidikan yang diharapkan dapat membekali dan menumbuhkan kreativitas, produktivitas, dan mempersiapkan peserta didik menghadapi kemajuan zaman.

Kemajuan di semua aspek kehidupan menghasilkan tuntutan berat pada para pendidik (guru). Mereka harus mampu untuk menghubungkan kegiatan di dalam pembelajaran dengan masalah pada kehidupan nyata, sehingga pembelajaran yang didapat di bangku sekolah 
dapat diterapkan pada masyarakat dan lingkungan. Karena itu, peserta didik diharapkan dapat menguasai berbagai keterampilan abad 21 yang terangkum dalam 4C, yaitu: Critical thinking and problem solving, Collaboration, Creativity dan Communication (Roekel, 2018). Namun, Jauh panggang dari api. kenyataan di lapangan sangat berbeda sekali dari harapan. Hasil riset dan studi mengungkapkan bahwa pembelajaran yang mengasah kemampuan $4 \mathrm{C}$ peserta didik masih sangat minim, terutama kemampuan berpikir kritis dan berpikir kreatif (Fuad, Zubaedah, Mahanal, \& Suarsini, 2015).

Selain dituntut untuk menghadirkan karakteristik abad 21 berupa: critical thinking and problem solving, collaboration, creativity dan communication pada peserta didik, guru juga harus mempersiapkan peserta didik menghadapi persaingan dan kehidupan revolusi industri 4.0. dengan kata lain pembelajaran harus mengacu pada kebutuhan. Karena itu, pembelajaran yang dilakukan harus terintegrasi. Sains, Teknologi, Enginering, Art and Mathematic (STEAM) adalah disiplin ilmu yang sangat penting bagi masyarakat pada era revolusi industri 4.0. STEAM mempengaruhi banyak hal penting. Sains dan Matematika memberikan jawaban atas pertanyaan mendasar tentang alam dan memungkinkan untuk memahami dunia di sekitar. Penguasaan terhadap STEAM memungkinkan untuk mengukur, menganalisis, dan merancang serta memajukan lingkungan fisik dapat meningkatkan kualitas hidup, terutama melalui perkembangan dalam perawatan kesehatan.

Keahlian menerapkan STEAM di dalam pembelajaran diperlukan untuk mendorong pertumbuhan ekonomi, inovasi, dan memberikan fondasi bagi kemakmuran masa depan bangsa. Salah satu faktor yang mempengaruhi ketercapaian tujuan pembelajaran adalah adanya interaksi positif antara guru dan peserta didik. Selain menyampaikan ilmu dan pengetahuan, mendidik peserta didik agar bisa mempunyai sikap utama juga merupakan tugas guru. Dalam rangka mewujudkan hal tersebut, maka guru harus merencana proses pembelajaran yang akan 
dilaksanakan dengan baik. tidak lupa juga harus menyediakan sumber belajar dan suasana yang nyaman serta menyenangkan (Hamalik, 2011).

Meskipun telah menggunakan Kurukulum 2013, proses pembelajaran tematik yang dilakukan di SDN Langenharjo 2 setiap hari masih sering menggunakan metode yang kurang sesuai dengan indikator tema yang diajarkan. Kesenjangan hubungan antara guru dan peserta didik sangat terasa. Fungsi utama guru sebagai fasilitator tidak terjadi. Peserta didik lebih banyak pasif: guru menjadi pelaku utama pada proses pembelajaran (teacher centered). Penyebab kondisi ini adalah guru tidak merencanakan pembelajaran dengan baik, selain itu guru juga tidak menggunakan media/alat pembelajaran yang sesuai.

Berdasar studi awal yang dilakukan dengan observasi terhadap pelaksanaan pembelajaran di SDN Langenharjo 2, ternyata pembelajaran belum memuat karateristik abad 21 secara optimal. Karakteristik berkomunikasi (communication) sebesar 56\%, berkolaborasi (collaboration) sebesar $62 \%$, berpikir kritis dan pemecahan masalah (critical thinking and problem solving) hanya sekitar $20 \%$, kreativitas (creativity) sekitar $16 \%$. Pembelajaran yang dilakukan masih belum seutuhnya terintegrasi pembelajaran tematik: masih terasa seperti mata pelajaran yang terpisahpisah.

Penyebab keadaan tersebut diduga karena guru belum membuat perencanaan pembelajaran yang di dalamnya memuat penerapan keterampilan abad 21, selain itu juga belum menggunakan media pembelajaran yang sesuai sehingga aktivitas pembelajaran belum mengasah kemampuan peserta didik secara optimal terutama pada keterampilan abad 21. Faktor-faktor ini mengakibatkan penerapan proses pembelajaran Critical thinking and problem solving, Collaboration, Creativity dan Communication (4C) tidak dapat dicapai dan dilaksanakan dengan optimal.

Keberhasilan pembelajaran tidak hanya diukur dari penguasaan peserta didik pada pelajaran. Akan tetapi lebih lanjut dapat dilihat dari 
proses pembelajaran yang dilakukan serta situasi di dalam pembelajaran. Di dalam rangka mewujudkan hal itu, dibutuhkan sebuah model dan media pembelajaran yang sesuai dengan materi pembelajaran, serta di dukung dengan perencanaan dan pelaksanaan proses pembelajaran yang baik. Media pembelajaran yang dimaksud adalah Simple Rocket Design yang disingkat menjadi sebuah akronim SIM-ROSI.

SIM-ROSI adalah media yang dikembangkan dengan tujuan untuk meningkatkan karakteristik abad 21 bagi siswa pada proses pembelajaran di sekolah dasar, khususnya pada materi tematik tema 7 kelas 3 sekolah dasar. Selain sederhana dan aman, media ini juga dikembangkan dengan metode pembelajaran STEAM. Hal ini menjadikan SIM-ROSI sebagai sebuah media pembelajaran yang memang layak digunakan dalam pembelajaran di sekolah dasar.

\section{B. Metode}

Pembuatan SIM-ROSI didasari oleh keprihatinan pengembang ketika melihat pelaksanaan proses dan hasil belajar tematik di SDN Langenharjo 2 Kecamatan Plemahan Kabupaten Kediri tidak optimal. Hasil observasi awal pembelajaran menunjukkan bahwa pembelajaran yang dilakukan sangat jauh dari makna pembelajaran tematik. Pembelajaran yang dilakukan belum dapat mempersiapkan peserta didik menghadapi geliat kemajuan zaman pada era revolusi industri 4.0 serta belum bisa memberikan bekal pada peserta didik di dalam menghadapi persaingan abad 21.

Menurut observasi awal yang dilakukan oleh pengembang, terdapat beberapa masalah yang perlu untuk di rubah dan diperbaiki di dalam proses pembelajaran, masalah tersebut yaitu: (1) pembelajaran yang dilakukan belum dapat seutuhnya menjadikan peserta didik menjadi aktif. Masih banyak peserta didik yang hanya menjadi objek pembelajaran saja; (2) peserta didik lebih banyak menyelesaikan soal-soal yang ada di buku, belum ada pengembangan dalam pembelajaran 
terutama yang mengarah pada keterampilan abad 21; (3) media pembelajaran yang digunakan belum mengarah pada pengembangan karakteristik abad 21. Berdasar hasil observasi tersebut, pengembang mempunyai gagasan untuk melakukan sebuah penelitian pengembangan terkait dengan pembuatan suatu media pembelajaran dengan teknik $4 \mathrm{D}$ menurut Thiagarajan. Media yang dikembangkan berbasis model pembelajaran Project Based Learning (PjBL) dan melalui pendekatan Sains, Teknologi, Enginering, Art, and Math (STEAM). Media yang dimaksud tersebut adalah Simple Roket Design (SIM-ROSI).

SIM-ROSI merupakan sebuah gambar rancangan proyek yang harus dibuat/dilakukan oleh siswa. Secara umum tujuan pengembangan media ini adalah agar terjadi peningkatan peran serta peserta didik dalam proses belajar secara optimal, ini berarti pembelajaran yang awalnya terpusat pada guru (teacher centered) berubah menjadi terpusat pada peserta didik (student centered). Untuk mewujudkan hal ini, pengembang mempunyai gagasan menciptakan sebuah rancangan pembelajaran berbasis proyek. Dengan proyek ini, diharapkan peserta didik dapat mengembangkan kemampuan dan keterampilan berbasis karakteristik abad 21, yaitu: berkomunikasi, berkolaborasi, berpikir kritis dan pemecahan masalah, serta kreatifitas.

Untuk melengkapi proyek tersebut, pembelajaran disusun berbasis model pembelajaran PjBL dan melalui pendekatan STEAM. Hal ini dilakukan dengan tujuan untuk membangkitkan dan mengasah kemampuan peserta didik di dalam aktivitas belajarnya, dirancang untuk dikerjakan secara bersama-sama, sehingga agar dapat menyelesaikan proyek harus ada komunikasi yang baik di antara mereka. Fathurahman yang menyatakan bahwa, "Model pembelajaran berbasis proyek merupakan ajang kesempatan berdiskusi yang bagus bagi peserta didik." (Fathurrrohman, 2015). Rancangan produk proyek tersebut juga dilengkapi dengan aktivitas yang memuat sains, teknologi, engineering, art dan juga math. 
Teknik pengumpulan data untuk mengetahui keberhasilan dilakukan dengan metode kuesioner dan observasi. Kuesioner digunakan untuk mengukur kemudahan dalam pemakaian media dan keberhasilan penggunaan media pembelajaran oleh peserta didik. Observasi dilakukan untuk melihat hasil dari aktivitas peserta didik dalam proses pembelajaran, khususnya kemampuan $4 \mathrm{C}$ peserta didik. Data hasil pembelajaran berbasis proyek yang telah terkumpul berupa angket dan observasi selanjutnya dianalisis menggunakan uji statistik dan analisis deskriptif

SIM-ROSI adalah sebuah media pembelajaran berbasis pendekatan STEAM yang dirancang sedemikian rupa berdasar metode penelitian dan pengembangan media pembelajaran model Thiagarajan yang disebut dengan 4D (Sugiyono, 2017). Urutan langkah pembuatan SIM-ROSI menggunakan metode penelitian dan pengembangan Thiagarajan dilakukan dengan langkah-langkah sebagai berikut:

\section{Tahap Pendefinisian}

Pada tahap pendefinisian yang dilakukan pertama kali adalah melakukan analisis untuk mengetahui kondisi awal peserta didik dan guru. Berdasarkan observasi keadaan peserta didik kelas III dalam pembelajaran tema 7 masih hanya sebatas teori. Banyak peserta didik yang kurang bisa menyebutkan perubahan energi. Selain itu, materi yang mereka terima hanya terbatas pada pengetahuan saja. Peserta didik lebih cenderung sebagai objek di dalam proses pembelajaran. Hal ini tidak sesuai dengan pola pembelajaran berdasar karakteristik abad 21.

Langkah kedua dalam tahap perencanaan yaitu menentukan tujuan instruksional. Pada langkah ini pengembang perlu menentukan tujuan pembelajaran atau yang dapat dicapai oleh peserta didik ketika atau setelah menggunakan media SIM-ROSI. Tujuan pembelajaran termuat pada silabus dan buku guru kelas III tema 7 tentang energi dan perubahannya. Tujuan yang pertama, yaitu: agar peserta didik dapat 
menggali informasi tentang sumber dan bentuk energi yang disajikan dalam bentuk lisan, tulis, visual, dan/atau eksplorasi lingkungan. Selain itu, tujuan dalam pengembangan media pembelajaran ini yaitu untuk membuat media pembelajaran yang layak untuk digunakan peserta didik kelas III dalam pembelajaran sehingga pembelajaran dapat berlangsung efektif.

Penentuan materi dilakukan setelah menentukan tujuan pembelajaran dan pengembangan. Materi pengembangan media SIMROSI, yaitu: pengembangan alat ukur keberhasilan. Alat pengukur ini harus dikembangkan sesuai dengan tujuan tentang energi dan perubahannya yang terdapat pada buku guru dan buku peserta didik kelas III tema 7 sekolah dasar. Menentukan alat ukur keberhasilan berupa instrumen untuk uji coba media pada penilaian layak dan tidaknya suatu media dan soal tertulis untuk menentukan keefektifan suatu media.

\section{Tahap Perancangan}

Tahap yang kedua pada model ini adalah proses membuat perancangan, yaitu pengembang membuat dan merancang unsur STEAM, karakteristik abad 21, dan membuat prototipe SIM-ROSI. Unsur STEAM dan karakteristik pembelajaran abad 21 yang terkandung di dalam pembuatan SIM-ROSI.

Perancangan materi sains dilakukan dengan melakukan uji coba langsung perubahan energi dari energi kimia menjadi energi gerak. Kegiatan ini dilakukan dengan cara melakukan uji coba pencampuran larutan kimia dengan soda kue. Pencampuran ini dilakukan di dalam badan roket yang kemudian ditutup dengan tutup dari bekas sandal jepit agar menghasilkan daya dorong yang akhirnya menjadi gaya gerak. Pada proses pencampuran ini terdapat karakteristik abad 21 berupa: collaboration, critical thinking, serta comunication.

Kegiatan teknologi dan engineering dilakukan peserta didik di dalam pembelajaran dengan cara membuat bahan berdasar rancangan 
serta merangkai rancangan yang telah dibuat tersebut agar menjadi sebuah benda yang dapat digunakan. Sedangkan karakteristik pembelajaran abad 21 yang dilakukan oleh peserta didik adalah: collaboration, communication, critical thinking, problem solving (4c).

Art dalam bahasa Indonesia disebut dengan seni. Sehingga pembelajaran yang berlangsung juga berhubungan dengan seni. Adapun di sekolah dasar, pembelajaran yang dimaksud adalah pembelajaran SBdP. Di dalam pembelajaran ini, unsur art dilakukan peserta didik pada saat melakukan kegiatan menghias permukaan SIM-ROSI dengan unsur seni rupa, misalnya menggambar dan memberi tempelan. Karakteristik keterampilan abad 21 yang dilakukan oleh peserta didik adalah: collaboration, communication, critical thinking, problem solving.

Unsur math atau matematika pada SIM-ROSI dilakukan peserta didik dalam beberapa kegiatan, salah satunya adalah kegiatan pengukuran. Sengaja SIM-ROSI tidak diberi ukuran yang pasti, hal ini dilakukan dengan tujuan agar peserta didik dapat melatih kemampuan berpikir kritis serta berlatih mengukur, di antaranya yaitu: mengukur panjang diameter botol dan mengukur panjang dan tinggi bahan. Selain pengukuran, peserta didik juga dikenalkan dengan bentuk bangun datar persegi panjang dan segi tiga, serta bangun ruang berupa kerucut. Selain itu, peserta didik juga dituntut mengenal unsur pecahan di di dalam proses pembuatan. Sedangkan karakteristik pembelajaran abad 21 yang dilakukan oleh peserta didik adalah: collaboration, communication, critical thinking, problem solving.

Selanjutnya Prototipe yang dibuat berupa sebuah gambar desain rancangan roket. Rancangan tersebut berupa gambar berikut ini: 


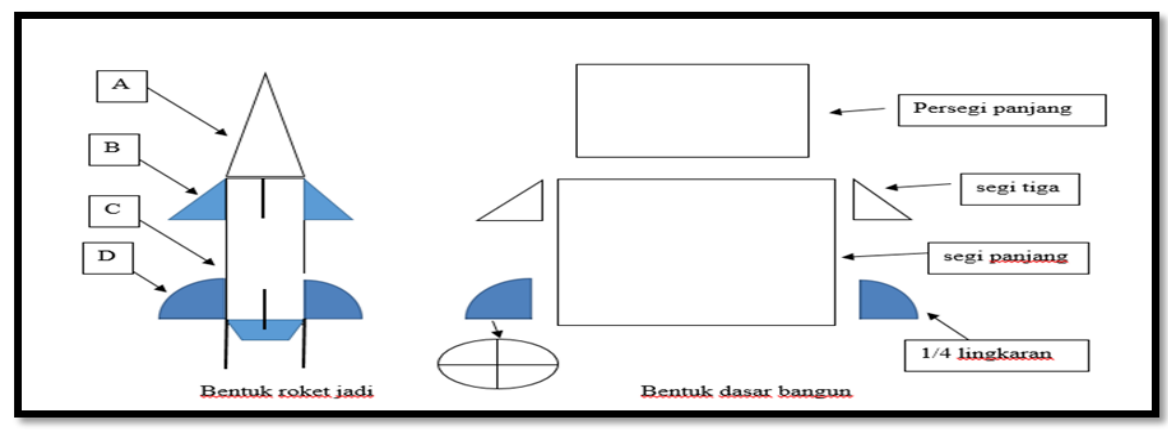

Gambar 1 Desain SIM-ROSI

Gambar rancangan desain SIM-ROSI terdiri dari: A) adalah kerucut yang terbentuk dari potongan karton berbentuk persegi panjang; B) segitiga yang berjumlah 4 buah untuk keseimbangan; C) tabung yang terbuat dari bentuk dasar potongan karton persegi panjang. Bagian utamanya berupa botol plastik air mineral; D) 1/4 lingkaran yang terbuat dari lingkaran utuh yang dibagi 4 .

Pada tahap ini, pengembang juga menyediakan alat dan bahan yang akan digunakan. Rincian alat dan bahan diuraian pada tabel di bawah ini:

Tabel 1 alat dan bahan pembuat SIM-ROSI

\begin{tabular}{cll}
\hline No & Alat & Bahan \\
\hline 1 & Gunting & Kardus \\
2 & Cutter & Soda kue \\
3 & Penggaris & Larutan Cuka \\
4 & Lem kertas & Kertas karton \\
5 & Karet sandal jepit & Kertas gambar \\
6 & Isolasi & Kertas warna \\
\hline
\end{tabular}

Untuk uji coba media SIM-ROSI, penyusunan kisi-kisi validasi dilakukan pada tahap perancangan. Alat dan bahan dirangkai sesuai dengan prototipe yang sudah disusun pada tahap berikutnya. 


\section{Tahap pengembangan (develop)}

Alat dan bahan yang sudah disiapkan, dirangkai merujuk pada desain yang sudah dibuat. Botol air mineral bekas diukur untk menyesuaikan ukuran potongan bahan. Kertas karton dipotong-potong sesuai bentuk desain. Untuk melekatkan karton pada botol digunakan double tip dan isolasi. Setelah potongan selesai ditempel, permukaan bentuk roket dihias dengan kertas warna-warni agar tampilan menarik. Setelah tahap ini selesai maka roket siap diuji kelayakannya.

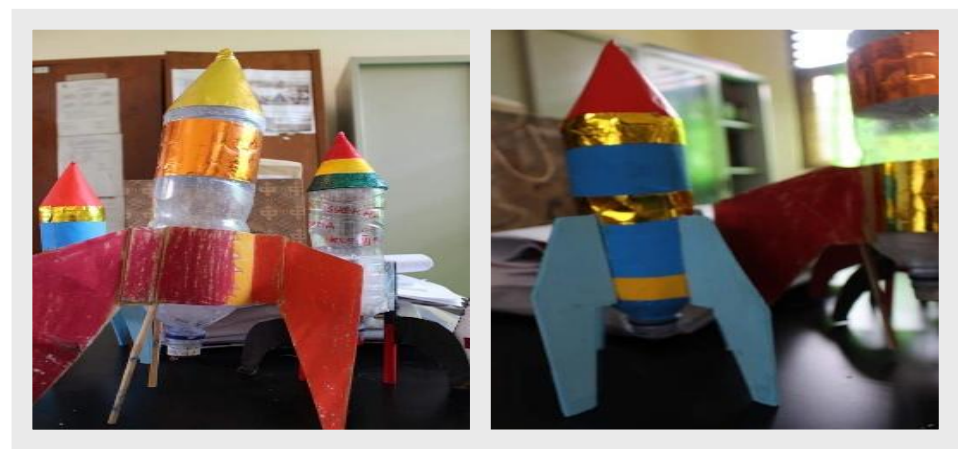

Gambar 2 SIM-ROSI selesai dirakit

Pada tahap ini media diujikan kepada ahli media dan ahli materi. Tujuan dari ahli media untuk mendapatkan penilaian layak dan tidaknya media ini digunakan dalam pembelajaran. Penilaian dari ahli materi adalah untuk mengetahui layak atau tidaknya materi yang disampaikan. Selain itu juga untuk mendapatkan masukan/saran agar media layak digunakan dalam pembelajaran.

\section{Tahap penyebaran (disseminate)}

Tahap penyebaran ini dilakukan oleh penulis yang pertama pada teman sejawat di SDN Langenharjo 2 Kecamatan Plemahan Kabupaten Kediri. Selanjutnya pada kegiatan Kelompok kerja guru atau KKG Gugus 1 Kecamatan Plemahan dan pada KKG kelas 3 pada tingkat Kecamatan Plemahan. Selain itu pada Komunitas guru yang ada di Kabupaten Kediri. 
Pada diseminasi tersebut, dijelaskan secara gamblang bagaimana tatacara teknik pembuatan dan sekaligus penggunaan SIM-ROSI berbasis PjBL dan STEAM di dalam pembelajaran. Hampir seluruh peserta terlihat sangat antusias dan mereka mempunyai rencana menerapkannya di dalam kelas. Serta banyak yang berencana membuat proyek-proyek serupa guna meningkatkan proses dan hasil belajar peserta didik. Di dalam kegiatan tersebut, para peserta memberikan masukan terhadap media. Masukan yang diperoleh dari kegiatan penyebaran akan digunakan sebagai salah satu perbaikan dan penyempurnaan produk

\section{Hasil dan Pembahasan}

SIM-ROSI digunakan pada pembelajaran tematik pada tema 7 kelas 3 sekolah dasar. Ukuran keberhasilan penggunaan media dapat dilihat dalam pengambilan data yang dilaksanakan, yaitu berdasar kuesioner tertututup berupa angket dan penilaian proses melalui observasi pada saat berlangsungnya pembelajaran.

\section{Hasil}

a. Data Hasil Validasi Ahli Media dan Materi

Sebelum digunakan pada pembelajaran media diujikan kepada ahli media dan ahli materi. Tujuan pengujian dari ahli media adalah untuk mendapatkan penilaian layak dan tidaknya media ini digunakan dalam pembelajaran. Sedangkan penilaian dari ahli materi adalah untuk mengetahui layak atau tidaknya materi yang disampaikan. Selain itu juga untuk mendapatkan masukan/saran agar media layak digunakan dalam pembelajaran. Hasil validasi ahli media dan ahli materi dapat dilihat pada tabel berikut:

Tabel 2 Hasil validasi ahli media dan materi SIM-ROSI

Uji Coba Hasil Keterangan Komentar dan Saran

\begin{tabular}{llll}
\hline Ahli Materi & $86,25 \%$ & Sangat layak, Secara umum dapat
\end{tabular}




\begin{tabular}{|c|c|c|c|}
\hline & & $\begin{array}{l}\text { dapat } \\
\text { digunakan } \\
\text { tanpa perbaikan }\end{array}$ & $\begin{array}{l}\text { digunakan untuk } \\
\text { menyampaikan materi } \\
\text { tematik. }\end{array}$ \\
\hline Ahli Media & $87,27 \%$ & $\begin{array}{l}\text { Sangat layak, } \\
\text { dapat } \\
\text { digunakan } \\
\text { dengan sedikit } \\
\text { perbaikan }\end{array}$ & $\begin{array}{l}\text { Secara umum dapat } \\
\text { digunakan media } \\
\text { pembelajaran, tetapi perlu } \\
\text { perbaikan }\end{array}$ \\
\hline
\end{tabular}

Berdasar tabel di atas, uji coba yang dilakukan ahli materi mendapat persentase dengan nilai $86,25 \%$ dengan kriteria layak digunakan di dalam pembelajaran tematik. Sedangkan validasi ahli media memperoleh nilai sebesar $87,27 \%$ dengan kriteria sangat layak digunakan untuk menyampaikan materi Tematik. Namun, di dalam kriteria sangat layak ini terdapat sedikit perbaikan. Terutama pada tutup peluncur roket yang berbahan balon karet agar diganti menjadi karet yang lebih aman. Saran dari para ahli ini digunakan sebagai dasar untuk memperbaiki media.

\section{b. Data Hasil Uji Coba Lapangan}

Setelah itu, barulah media diujicoba pada peserta didik. Setelah itu, barulah media diujicoba pada peserta didik. Tahap uji coba pertama dilakukan oleh 3 orang peserta didik yang memiliki kemampuan sedang, tinggi dan rendah.

Tabel 3 Hasil uji coba oleh siswa

\begin{tabular}{lcll}
\hline \multicolumn{1}{c}{ Uji Coba } & Hasil & \multicolumn{1}{c}{ Keterangan } & Komentar dan Saran \\
\hline $\begin{array}{l}\text { Uji coba } \\
\text { perorangan }\end{array}$ & $83,45 \%$ & $\begin{array}{l}\text { Sangat layak, dapat } \\
\text { digunakan tanpa } \\
\text { perbaikan }\end{array}$ & $\begin{array}{l}\text { Isolasi dan double } \\
\text { tipe terlalu kecil } \\
\text { sehingga sulit untuk } \\
\text { menempelkan kertas }\end{array}$ \\
\hline
\end{tabular}




\begin{tabular}{lcl}
$\begin{array}{l}\text { Uji coba } \\
\text { kelompok } \\
\text { kecil }\end{array}$ & $86,68 \%$ & $\begin{array}{l}\text { Sangat layak, dapat } \\
\text { digunakan tanpa } \\
\text { perbaikan }\end{array}$ \\
$\begin{array}{l}\text { Uji coba } \\
\text { lapangan }\end{array}$ & $88,30 \%$ & $\begin{array}{l}\text { Sangat layak, dapat } \\
\text { digunakan tanpa } \\
\text { perbaikan }\end{array}$ \\
\hline
\end{tabular}

c. Data Hasil Pendapat Peserta Didik (Angket)

Untuk mengetahui pendapat peserta didik tentang penggunaan SIM-ROSI, digunakan survei skala Likert berisi pendapat peserta didik tentang penggunaan media yang telah dilakukan. Bobot tertinggi di setiap pertanyaan adalah 4 dan bobot terendah adalah 1 . Setelah diakumulasi diperoleh data isian angket peserta didik berikut:

Tabel 4 Hasil kuesioner angket peserta didik

\begin{tabular}{|c|c|c|c|c|c|}
\hline No & Indikator & SS & $S$ & TS & STS \\
\hline 1 & senang dengan pembelajaran & 22 & - & - & - \\
\hline 2 & $\begin{array}{l}\text { berbicara dan berdiskusi dengan teman } \\
\text { kelompok (communication) }\end{array}$ & 22 & - & - & - \\
\hline 3 & saling bantu dan bekerjasama (collaboration) & 20 & 2 & - & - \\
\hline 4 & $\begin{array}{l}\text { permasalahan sulit yang harus difikirkan dan } \\
\text { diselesaikan(critical thinking and problem } \\
\text { solving)) }\end{array}$ & 21 & 1 & - & - \\
\hline 5 & berkreasi/mencipta karya seni (Creativity) & 20 & 2 & - & - \\
\hline
\end{tabular}

d. Hasil observasi pada Proses Pembelajaran

SIM-ROSI bertujuan untuk meningkatkan efektifitas proses pembelajaran berdasar karakteristik abad 21 (4C). Adapun aspek yang dinilai dalam penilaian proses adalah : a). communication; b). Collaboration; c). critical thinking; d). problem solving kemampuan berbicara. Adapun rincian pengamatan proses dalam pembelajaran disajikan dalam tabel berikut: 
Ah. Burhanudin

Tabel 5 Hasil penilaian proses pada aspek $4 \mathrm{C}$

\begin{tabular}{clc}
\hline No & \multicolumn{1}{c}{ Aspek } & rata-rata \\
\hline 1 & Communication & 4.91 \\
2 & Collaboration & 4.95 \\
3 & Critichal Thinking and Problem Solving & 4.86 \\
4 & Creativity & 4.73 \\
\hline
\end{tabular}

\section{Pembahasan}

a. Analisis Keberhasilan penggunaan Media SIM-ROSI

Setelah dilakukan observasi kepada peserta didik kelas III SDN Langenharjo 2 yang dilaksanakan dengan angket tertutup, didapatkan akumulasi hasil data dari isian angket yang disajikan dalam tabel berikut:

Tabel 6 Persentase skor angket peserta didik

\begin{tabular}{clc}
\hline No & \multicolumn{1}{c}{ Indikator } & Skor \\
\hline 1 & senang dengan pembelajaran & 88 \\
2 & $\begin{array}{l}\text { berbicara dan berdiskusi dengan teman } \\
\text { kelompok (communication) }\end{array}$ & 88 \\
3 & saling bantu dan bekerjasama (collaboration) & 86 \\
4 & $\begin{array}{l}\text { permasalahan sulit yang harus difikirkan dan } \\
\text { diselesaikan(critical thinking and problem solving) }\end{array}$ & 87 \\
5 & $\begin{array}{l}\text { berkreasi/mencipta karya seni (Creativity) } \\
\text { Jumlah Skor }\end{array}$ & 86 \\
& Rata-Rata & 435 \\
& & 87,0 \\
\hline
\end{tabular}

Berpedoman pada hasil tabel tersebut, dapat diartikan bahwa menurut responden (peserta didik), peserta didik terlihat sangat aktif, antusias, dan senang dalam pelaksanaan pembelajaran berbasis proyek. Mereka dapat benar-benar mengikuti pembelajaran dengan aktif. Pernyataan tentang apakah mereka senang dengan pembelajaran yang telah dilakukan memperoleh skor 88, skor ini membuktikan bahwa SIMROSI berbasis $P j B L$ dan STEAM sangat baik untuk diterapkan apabila 
ditinjau dari kemudahan penggunaan dalam pembelajaran. Hal ini membuktikan bahwa seluruh responden/peserta didik menyatakan merasa senang dengan pembelajaran yang dilakukan.. Hasil ini memang sangatlah wajar, karena dengan aktivitas proyek berbasis STEAM hampir seluruh peserta didik dapat beraktivitas sesuai dengan kompetensi masing-masing tanpa adanya tekanan.

Pernyataan tentang efektifitas media dalam membantu peserta didik dalam berkomunikasi dengan orang lain (communication) sangat tidak diragukan lagi, berdasar hasil angket yang dibagikan kepada peserta didik memperoleh skor 88. Hal ini menyatakan bahwa SIM-ROSI berbasis PjBL dan STEAM membantu peserta didik dalam berkomunikasi dengan orang lain (communication) dengan sangat baik. Tidak dapat dipungkiri memang banyak faktor yang mendukung peserta didik untuk berkomunikasi dengan anggota lain dalam satu kelompok, ataupun kelompok lain. Hal ini memang sesuai dengan rencana awal, bahwa SIM-ROSI memang dirancang untuk dikerjakan secara bersama-sama, untuk dapat menyelesaikan proyek harus ada komunikasi yang baik di antara para peserta didik. Hal ini sesuai dengan pendapat Fathurahman yang menyatakan bahwa, "Model pembelajaran berbasis proyek merupakan ajang kesempatan berdiskusi yang bagus bagi peserta didik." (Fathurrrohman, 2015).

Berikutnya, pernyataan tentang kemampuan SIM-ROSI berbasis PjBL dan STEAM untuk memfasilitasi peserta didik untuk saling bantu dan bekerjasama (collaboration) mendapat skor 86 . Hal ini menunjukkan bahwa SIM-ROSI berbasis PjBL dan STEAM dapat membantu peserta didik untuk berkolaborasi dengan sangat baik.

Selanjutnya, pernyataan tentang SIM-ROSI berbasis $P j B L$ dan STEAM untuk memfasilitasi peserta didik untuk dapat berpikir kritis (critical thinking) dan memecahkan/menyelesaikan masalah (problem solving) mendapat skor 87. Hal ini menunjukkan bahwa SIM-ROSI berbasis $P j B L$ dan STEAM bisa membantu peserta didik untuk berpikir kritis (critical thinking) dan memecahkan/menyelesaikan masalah (problem solving) dengan sangat baik. 
Pernyataan tentang kemampuan SIM-ROSI berbasis PjBL dan STEAM untuk memfasilitasi peserta didik untuk berkreasi (creativity) mendapat skor 86. Hal ini menunjukkan bahwa SIM-ROSI berbasis PjBL dan STEAM benar-benar dapat membantu peserta didik untuk dapat berkreasi (creativity) dengan sangat baik.

Keseluruhan data yang di peroleh tersebut dapat dikerucutkan menjadi sebuah kesimpulan bahwa tanggapan peserta didik terhadap seluruh variabel mendapat respon yang sangat baik. Hasil angket dari responden sebanyak 22 peserta didik menyatakan bahwa penggunaan SIM-ROSI berbasis PjBL dan STEAM sangatlah tepat, efektif dan menyenangkan. Hal ini dapat dilihat dari hasil skor sebesar 435 dengan rata-rata skor 87,0 . termasuk dalam interval antara 71 - 88 yang berarti Sangat Baik. Hal ini menunjukkan bahwa, penggunaan media dapat berpengaruh positif terhadap peserta didik dengan sangat

b. Analisis Penilaian Proses dalam pembelajaran

Secara umum proses pembelajaran berlangsung dengan sangat baik. Sesuai dengan rencana penggunaan SIM-ROSI berbasis PjBL dan STEAM. Aktivitas peserta didik meningkat menjadi lebih baik jauh dari sebelumnya. Pengambilan keputusan di dalam pengembangan ini diambil berdasar rata-rata hasil observasi dan taraf signifikansi. Langkah pertama yang dilakukan menentukan naik atau tidaknya nilai rata-rata berdasarkan mean dan berdasar signifikansi. Hasil penilaian proses penggunaan SIM-ROSI berbasis $P j B L$ dan STEAM dapat diamati pada diagram di bawah ini:

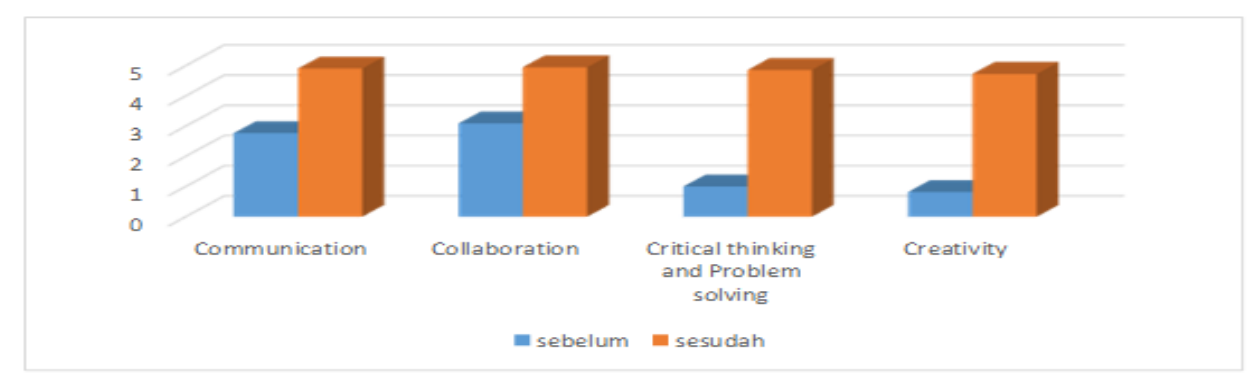

Gambar 3 Diagram hasil penilaian proses 
Pengambilan keputusan berdasar mean dilakukan dengan cara melihat langsung output dari kolom mean yang ada pada tabel paired samples statistics (Priyatno, 2016). Sedangkan pengambilan keputusan berdasar signifikansi dilakukan melalui tahap menentukan hipotesis pertama $\left(\mathrm{H}_{0}\right)$ dan hipotesis alternatif $\left(H_{n}\right)$. Hipotesis pertama $\left(H_{0)}\right.$, yaitu ada perbedaan rata-rata nilai sebelum dan sesudah menggunakan SIMROSI berbasis PjBL dan STEAM. Hipotesis alternatif $(\mathrm{Ha})$ : tidak ada perbedaan rata-rata nilai sebelum dan sesudah menggunakan SIM-ROSI berbasis PjBL dan STEAM.

Penentuan taraf signifikansi dilakukan dengan melihat output kolom signifikansi pada tabel Paired Samples Test dengan ketentuan apabila nilai signifikansi $>0,05$ maka $H_{0}$ diterima, dan apabila nilai signifikansi $<0,05$ maka $H_{0}$ ditolak. Hasil analisis data terhadap proses karakteristik abad 21 di dalam pembelajaran pada aspek communication dapat diamati pada tabel di bawah ini:

Tabel 7 Paired samples statistics communication

\begin{tabular}{llllll}
\hline & & & & \multicolumn{2}{l}{ Std. Error } \\
& & Mean & $\mathrm{N}$ & Std. Deviation & Mean \\
\hline Pair 1 & C1 sebelum SIM-ROSI & 2.77 & 22 & .528 & .113 \\
& C1 menggunakan SIM- & 4.91 & 22 & .294 & .063 \\
& & & & \\
\hline
\end{tabular}

Berdasar observasi yang dilakukan terhadap nilai rata-rata aspek communication yang awalnya hanya 2,77 , setelah menggunakan SIMROSI berbasis PjBL dan STEAM meningkat menjadi 4,98. Nilai rata-rata Communication setelah menggunakan SIM-ROSI lebih tinggi dari sebelumnya. Sedangkan untuk nilai signifikansi dapat dilihat pada tabel berikut: 
Tabel 8 Paired samples test communication

\begin{tabular}{llrrc}
\hline & $\mathrm{t}$ & $\mathrm{df}$ & Sig. (2-tailed) \\
\hline Pair 1 & $\begin{array}{l}\text { sebelum SIM-ROSI - } \\
\text { menggunakan SIM-ROSI }\end{array}$ & -17.886 & 21 & .000 \\
\hline
\end{tabular}

Berdasar tabel tersebut, apabila taraf signifikansi lebih kecil daripada 0,05 maka terjadi kenaikan aspek communication secara signifikan. Hal ini menunjukkan jika peserta didik sangat aktif dalam berkomunikasi, melakukan diskusi, dan berbagi ide dengan seluruh anggota kelompoknya. Proses pembelajaran pada mulanya memang sudah ada diskusi, tetapi hanya terbatas pada peserta didik yang kemampuan kognitif tinggi saja. Namun, setelah SIM-ROSI berbasis PjBL dan STEAM proses diskusi hampir merata pada seluruh peserta didik. Dalam hal ini guru berperan hanya sebagai fasilitator yang mengantarkan peserta didik menuju tujuan pembelajaran. sesuai dengan pendapat Fathurrrohman (2015) yang menyatakan bahwa peran pendidik dalam pembelajaran berbasis proyek adalah sebagai mediator dan fasilitator. Pendidik harus mampu memotivasi peserta didik agar mampu mengutarakan pendapatnya secara demokratis (Fathurrrohman, 2015).

Sedangkan kemampuan peserta didik pada aspek collaboration dapat dilihat pada tabel berikut:

Tabel 9 Paired samples statistics collaboration

\begin{tabular}{llllll}
\hline & & & & \multicolumn{2}{l}{ Std. Error } \\
& & Mean & $\mathrm{N}$ & Std. Deviation & Mean \\
\hline Pair & c2 sebelum SIM-ROSI & 3.09 & 22 & .426 & .091 \\
1 & c2 menggunakan SIM-ROSI & 4.95 & 22 & .213 & .045 \\
\hline
\end{tabular}

Berdasar tabel tersebut, kemampuan rata-rata peserta didik pada aspek collaboration meningkat pesat, observasi awal diketahui hanya sebesar 3,09 setelah menggunakan SIM-ROSI berbasis PjBL dan STEAM menjadi 4,95. Sedangkan untuk signifikansi dapat dilihat pada tabel berikut: 
Tabel 10 Paired samples test collaboration

\begin{tabular}{llllr}
\hline & $\mathrm{t}$ & $\mathrm{df}$ & \multicolumn{2}{c}{ Sig. (2-tailed) } \\
\hline Pair 1 & $\begin{array}{l}\text { C2 sebelum SIM-ROSI - c2 } \\
\text { menggunakan SIM-ROSI }\end{array}$ & -18.695 & 21 & .000 \\
\hline
\end{tabular}

Berdasar tabel tersebut, diketahui taraf signifikansi sebesar 0,000. Apabila taraf signifikansi lebih kecil daripada 0,05 maka terjadi kenaikan aspek Collaboration secara signifikan. Ini berarti hampir seluruh peserta didik dapat bekerjasama untuk menyelesaikan tugas dan proyek yang dilakukan. Mereka bekerjasama dan saling bantu di antara mereka. Sesuai dengan tujuan dan alasan diterapkannya $P j B L$ yaitu proses kerja kelompok yang saling mendukung untuk membuka berbagai peluang kreativitas (Fathurrrohman, 2015)

Analisis terhadap kemampuan berpikir kritis (critical thinking) peserta didik dinilai dari kemampuan peserta didik menjelaskan, menyimpulkan, mengatur strategi dan teknik, serta membangun keterampilan dasar (Maftukhin, 2013). Berdasar hasil analisis, kemampuan tersebut dapat dilihat pada tabel berikut:

Tabel 11 Paired samples statistics critical thinking and problem solving

\begin{tabular}{llllll}
\hline & & & \multicolumn{2}{c}{ Std. Error } \\
& & Mean & $\mathrm{N}$ & Std. Deviation & Mean \\
\hline \multirow{2}{*}{ Pair 1 } & c3 sebelum SIM-ROSI & 1.00 & 22 & .617 & .132 \\
& c3 menggunakan SIM- & 4.86 & 22 & .351 & .075 \\
& ROSI & & & & \\
\hline
\end{tabular}

Berdasar tabel tersebut, sebelum menggunakan SIM-ROSI berbasis PjBL dan STEAM, kemampuan berpikir kritis (critical thinking) peserta didik di dalam pembelajaran sangat rendah. Berdasar observasi hanya mempunyai nilai rata-rata 1,00. Namun, setelah menggunakan SIM-ROSI berbasis PjBL dan STEAM, aktivitas berpikir kritis peserta didik mengalami kemajuan menjadi 4,86. Sedangkan untuk signifikansi dapat dilihat pada tabel berikut: 
Tabel 12 Paired samples test critical thinking and problem solving

\begin{tabular}{llllr}
\hline & $\mathrm{t}$ & $\mathrm{df}$ & \multicolumn{2}{c}{ Sig. (2-tailed) } \\
\hline Pair 1 & $\begin{array}{l}\text { C2 sebelum SIM-ROSI - c2 } \\
\text { menggunakan SIM-ROSI }\end{array}$ & -25.518 & 21 & .000 \\
\hline
\end{tabular}

Berdasar tabel tersebut, diketahui taraf signifikansi sebesar 0,000. Apabila taraf signifikansi lebih kecil daripada 0,05 maka diketahui bahwa terjadi kenaikan aspek berpikir kritis dan pemecahan masalah (critical thinking and problem solving) secara signifikan. Ini berarti di dalam proses pembelajaran peserta didik melakukan kegiatan menjelaskan, menyimpulkan, mengatur strategi dan teknik, serta membangun keterampilan dasar di dalam proses pembelajaran. Pembelajaran menggunakan SIM-ROSI berbasis PjBL dan STEAM merupakan pembelajaran yang sangat baik. sesuai dengan pernyataan Zuhriyah (2013) bahwa sebuah pembelajaran yang baik hendaknya bisa membuat peserta didik untuk berpikir kritis. Kemampuan berpikir ini akan menjadikan mereka menjadi pribadi yang terbiasa menggunakan kemampuannya untuk menyelesaikan masalah yang dihadapi (Zuhriyah, 2013).

Adapun capaian hasil observasi terhadap aktivitas yang melibatkan pemecahan masalah dapat dilihat pada tabel berikut:

Tabel 13 Paired samples statistics creativity

\begin{tabular}{llrrrr}
\hline & & & & & Std. Error \\
& & Mean & N & Std. Deviation & Mean \\
\hline Pair 1 & c4 sebelum SIM-ROSI & .82 & 22 & .395 & .084 \\
& c4 menggunakan SIM-ROSI & 4.73 & 22 & .456 & .097 \\
\hline
\end{tabular}

Berdasar tabel tersebut, dapat diketahui bahwa aktivitas yang melibatkan pemecahan masalah di dalam pembelajaran yang awalnya hanya sebesar 0,82 setelah menggunakan SIM-ROSI berbasis PjBL dan STEAM berubah menjadi 4,73. Sedangkan untuk signifikansi dapat dilihat pada tabel berikut: 
Tabel 14 Paired samples test creativity

\begin{tabular}{|c|c|c|c|c|}
\hline & & $\mathrm{t}$ & $\mathrm{df}$ & Sig. (2-tailed) \\
\hline Pair 1 & $\begin{array}{l}\text { C2 sebelum SIM-ROSI - c2 } \\
\text { menggunakan SIM-ROSI }\end{array}$ & -25.518 & 21 & .000 \\
\hline
\end{tabular}

Berdasar tabel tersebut, diketahui bahwa taraf signifikansi sebesar 0,000. Diketahui apabila taraf signifikansi lebih kecil daripada 0,05 maka terjadi kenaikan aspek Creativity secara signifikan. Kenaikan rata-rata hasil observasi terhadap aktivitas yang melibatkan pemecahan masalah ini membuktikan bahwa SIM-ROSI berbasis PjBL dan STEAM mampu membuat peserta didik untuk berlatih memecahkan masalah selama proses pembelajaran berlangsung.

Keseluruhan data yang di peroleh tersebut dapat dikerucutkan menjadi sebuah kesimpulan bahwa penggunaan SIM-ROSI berbasis PjBL dan STEAM sangat sesuai untuk meningkatkan karakteristik abad 21 di dalam proses pembelajaran. Hal ini dibuktikan dari naiknya nilai rata-rata seluruh aspek karakteristik abad 21 di dalam proses pembelajaran dengan sangat signifikan.

\section{Penutup}

SIM-ROSI pada hakikatnya adalah sebuah media pembelajaran yang digunakan untuk pembelajaran pada siswa sekolah dasar kelas 3 tepatnya tema 7. Berbentuk rancangan gambar yang dibuat dengan teknik pengembangan media pembelajaran. Rancangan gambar tersebut merupakan sebuah proyek yang akan dilaksanakan oleh siswa. Dibuat dengan tujuan untuk meningkatkan kualitas aktivitas karakteristik abad 21 (4C) peserta didik di dalam proses pembelajaran. SIM-ROSI berbasis PjBL dan STEAM sangat efektif digunakan untuk meningkatkan aktivitas abad 21 yang berupa: collaboration, communication, creativity, critical thinking and problem solving (4C) peserta didik dalam pembelajaran. Hasil analisis dari penggunaan pada pembelajaran menunjukkan hasil yang sangat positif, yaitu meningkatnya aktivitas $4 C$ peserta didik dalam pembelajaran secara signifikan. Hal ini menjadikan SIM-ROSI sebagai 
sebuah media pembelajaran yang memang layak digunakan dalam pembelajaran di sekolah dasar

\section{Ucapan Terimakasih}

Terima kasih penulis sampaikan kepada Dinas Pendidikan Kabupaten Kediri, Pengawas TK/SD Korwil Kec. Plemahan, Ibu Sriani, S.Pd Kepala SDN Langenharjo 2 Kec. Plemahan, dan teman-teman guru yang tidak bisa kami sebutkan satu persatu, serta anak-anak Kelas III SDN Langenharjo 2 tahun pelajaran 2018/2019 yang membanggakan.

\section{Daftar Referensi}

Fathurrrohman, M. (2015). Paradigma Pembelajaran Kurikulum 2013. Yogyakarta: Kalimedia.

Fuad, N., Zubaedah, S., Mahanal, S., \& Suarsini, E. (2015). Profil Hasil Belajar, Keterampilan BerpikirKkritis dan Kreatif Peserta didik serta Strategi Pembelajaran yang diterapkan Guru SMP di Kabupaten Kediri. Proseding Seminar Nasional Biologi dan Pembelajarannya. Malang: Jurusan Biologi FMIPA UM.

Hamalik, O. (2011). Kurikulum dan Pembelajaran. Jakarta: Bumi Aksara.

Maftukhin, M. (2013). Skripsi: Keefektifan Model Pembelajaran CPS Berbantuan CD Pembelajaran Terhadapa kemampuan Berpikir Kritis Materi Pokok Geometri Kelas X. Semarang: Universitas Negeri Semarang.

Roekel, D. V. (2018). Preparing 21st Century Student foe a Global Society. Washington, D.C.: Washington, D.C. National Education.

Sugiyono. (2017). Metode Penelitian \& Pengembangan . Bandung: CV. Alfabeta.

Zuhriyah. (2013). Pengaruh Metode Problem Solving Terhadap Kemampuan Berpikir Kreatif dan Komunikasi dalam Pembelajaran IPS. Bandung: Repository.upi.eddu. 
Vol. 5, No. 1, Maret 2021 